DOI: $10.12775 /$ szhf.2013.011

RAFA£ MichalsKi

\title{
Estetyczne wątki w antropologii filozoficznej Arnolda Gehlena
}

\section{Uwagi wstępne}

Estetyka jak subdyscyplina filozoficzna jest stosunkowo młodą gałęzią refleksji i od samego początku wywołuje duże wątpliwości odnośnie do tego, co właściwie stanowi jej przedmiot i jaki jest zakres jej kompetencji. Jak pokazuje O. Marquard, powstanie estetyki w połowie XVIII wieku zbiegło się nieomal z narodzinami antropologii filozoficznej. Tym, co łączy antropologię z estetyką, są, według niego, dwa kluczowe motywy: za pierwszy z nich uznaje on odwrót od klasycznej metafizyki oraz od matematycznego przyrodoznawstwa, który pociągnął za sobą zwrot ku światu życia codziennego (Lebenswelt); drugim motywem jest natomiast wyzwolenie refleksji o człowieku z kontekstu filozofii dziejów, której towarzyszył zwrot do filozofii natury - jako filozofii natury człowieka (antropologia) bądź ku zmysłowości człowieka (estetyka) ${ }^{1}$. Estetykę i antropologię łączy ponadto zainteresowanie różnorodnością życia, wrażliwość na jego kontyngencję i niepowtarzalność, która wymyka się pojęciom aspirującym do ogólności i kategoryczności. Na potrzeby niniejszego artykułu możemy przyjąć, że obydwie dyscypliny filozoficzne znajdują się w sąsiadujących ze sobą terytoriach teoretycznej mapy współczesności. Estetyka skupiona na wartościach piękna, wzniosłości, brzy-

${ }^{1}$ O. Marquard, Schwierigkeiten mit der Geschichtsphilosophie, Frankfurt/M. 1973, s. 122-144. 
doty, wdzięku, siłą rzeczy musi zająć stanowisko wobec problematyki zmysłów, natury ludzkiego działania, wyobraźni, intelektu, bezinteresowności i symbolizmu, a zatem zagadnień, które stanowią również główny przedmiot dociekań antropologicznych. Na przykładzie filozofii A. Gehlena pokażemy, w jaki sposób można podjąć próbę połączenia obydwu dyscyplin, bez popadania w skrajności naturalizmu i kulturalizmu. W uwagach wstępnych ukazane zostaną główne antropologiczne założenia niemieckiego filozofa, następnie przedstawimy jego koncepcję genezy sztuki z archaicznych rytuałów (1), by w kolejnym paragrafie (2) omówić najważniejsze tezy dotyczące współczesnej sztuki wyrażone w pracy Zeit-Bilder².

Punktem wyjścia antropologii filozoficznej Gehlena jest teza o ustrojowych deficytach biologicznych homo sapiens. Człowiek to istota biologicznie ułomna, pozbawiona stabilnych instynktów, skanalizowanych popędów, nieprzystosowana do żadnego środowiska, pozbawiona wyspecjalizowanych organów ucieczki i ataku, rodząca się zbyt wcześnie z powodu nadmiernego rozrostu mózgu, wymagająca długotrwałej i uciążliwej opieki. Z wymienionych względów człowiek zmuszony jest wykorzystać mechanizmy kompensujące biologiczne braki. Główną instancją odciążającą okazuje się działanie, język oraz instytucje, które zdejmują z niego jarzmo podejmowania wciąż od nowa wysiłków służących przetrwaniu w nieprzyjaznym środowisku. Działanie przekształca zewnętrzne otoczenie na użytek człowieka, tworzy dostosowany do jego potrzeb świat drugiej natury, język oddramatyzowuje rzeczywistość, pozwala uwolnić się od nacisku aktualnej sytuacji, a tym samym planować i antycypować przyszłe zachowania, instytucje wreszcie stabilizują relacje międzyludzkie i dają jednostce normatywne oparcie. Tak w największym skrócie prezentują się główne założenia antropologiczne niemieckiego filozofa. W następnych paragrafach przyjrzymy się jego refleksji na temat sztuki prehistorycznej oraz współczesnej.

\section{1.}

Swoje rozważania na temat źródeł sztuki Gehlen przedstawia w pracy Urmensch und Spätkultur ${ }^{3}$. Filozof próbuje uniknąć w niej przeprowadzania analogii między sztuką współczesną i archaiczną, zakładając, że najstarsze

${ }^{2}$ A. Gehlen, Zeit-Bilder. Zur Soziologie und Ästhetik der modernen Malerei, Frankfurt/M. 1965.

${ }^{3}$ A. Gehlen, Urmensch und Spätkultur, Frankfurt/M. 2004. 
dostępne nam malowidła i kultowe artefakty były bezpośrednio związane z praktykami rytualnymi. Kolejnym założeniem jest idea, że formy postrzegania i interpretacji rzeczywistości ulegają historycznym przekształceniom. Doświadczenie człowieka prehistorycznego posiada zupełnie inną strukturę niż ta, która obecnie wyznacza obraz naszego świata, dlatego nie dysponujemy obecnie żadnymi hermeneutycznymi narzędziami, które pozwoliłyby nam uchwycić właściwy sens prehistorycznych dzieł sztuki, ani tym bardziej nie powinniśmy próbować sprowadzać ich do „czysto emocjonalno-estetycznej postaci”'. Jak poświadcza współczesna archeologia i antropologia kulturowa, źródeł sztuki prehistorycznej należy szukać w zachowaniach rytualno-przedstawieniowych.

Rytualno-przedstawieniowa forma zachowania od dawna nie towarzyszy już naszej praktyce, jej zanik można uznać za główne wydarzenie w historii kultury. Ponadto należy uwzględnić fakt, że stanowi ona istotny rys człowieczeństwa, dlatego w niej właśnie należy poszukiwać źródeł sztuki ${ }^{5}$.

Antropolog ma tutaj na myśli archaiczne obrzędy oparte na zbiorowym transie, orgiach, szamańskiej ekstazie, w których chodziło o instrumentalizację zachowań rytualnych w celu wyzwolenia sił witalnych tłumionych przez społeczne normy. Zrytmizowane zachowania, obrzędowe tańce, którym często towarzyszyło spożywanie środków odurzających, sztucznie eskalowały napięcie emocjonalne, by w ostatecznym rezultacie doprowadzić do rozładowania potencjalnie destrukcyjnych impulsów popędowych. Uwolnione „[...] afekty wyostrzały wrażliwość organizmu do takiego stopnia natężenia, którego nie pozwalały przewidzieć bezpośrednie konieczności życia. [...] Ryt stawał się wówczas środkiem służącym do wywołania subiektywnego lub kolektywnego stanu odurzenia"6. Gehlen podkreśla jednak, że najbardziej trwałe formy inwersji popędów związane były z technikami ekstazy opartymi na świadomej ascezie i samodyscyplinie. To właśnie za ich pośrednictwem dochodziło do stopniowej sublimacji stanów samoodczuwania, do rozwijania bezinteresownego, wolnego od nacisku afektów nastawienia wobec świata.

Aby wyjaśnić naturę działania rytualno-przedstawiającego, antropolog odwołuje się do tezy o konstytucjonalnym otwarciu człowieka na świat, nadając przy tej okazji pojęciu redukcji instynktów nowe znaczenie. Opierając się na

${ }^{4}$ Tamże, s. 55.

5 Tamże, s. 260.

${ }^{6}$ Tamże, s. 274. 
etologicznych badaniach K. Lorenza, filozof przyjmuje założenie, że sygnały wyzwalające reakcje instynktowne wśród zwierząt polegają na nieprawdopodobieństwie i prostocie. Wyzwalaczami są zatem zjawiska, które mają barwy spektralne albo rzadko spotykane cechy, odznaczają się regularną, niemal geometryczną postacią, symetrią, uporządkowaniem, precyzyjnym zrytmizowanym ruchem. Zgodnie z przyjętym przez Gehlena punktem widzenia redukcję instynktów należy rozumieć w ten sposób, że siły popędowe w człowieku nigdy nie są odprowadzane przez odgórnie ustalone schematy behawioralne. W przypadku sytuacji doniosłej biologicznie takie oderwanie bodźca kluczowego od instynktownych mechanizmów rozładowania popędu przenosi odpowiedź w sferę silnych uczuć. Zamiast instynktownej reakcji pojawia się zatem „przypływ uczucia”, który domaga się ujścia. W odpowiedzi człowiek może uruchomić zachowania nie powodujące żadnych skutków praktycznych.

Kiedy na przykład $\mathrm{w}$ otoczeniu pojawia się jakiś nieprawdopodobny „ostry” dźwięk, zwierzę reaguje przerażeniem i ucieczką, natomiast człowiek potrafi zatrzymać działanie wyzwalacza, czyli wywołany we wnętrzu „przypływ uczucia”, to zaś zatrzymanie stwarza lukę między aktualną podnietą i przesuniętym działaniem, w które wnika świadomość, aby wytłumaczyć sobie możliwe znaczenie tej sytuacji. W rzadkich przypadkach człowiek reaguje w quasi-instynktowny sposób na bodźce kluczowe, jak dowodzi tego etologia, ale zachowania te nie są ściśle zdeterminowane, a ponadto zachodzi przy tej okazji zjawisko zacierania różnic między wyzwalaczami. Na przykład cechy ludzkiego małego dziecka - stosunkowo duża, ciężka głowa, wysunięta do przodu czaszka, wysoko sklepione czoło, miękkie i elastyczne powierzchnie, krótkie i pulchne kończyny - wywołują opiekuńcze zachowania, a przynajmniej neutralizują i przekierowują agresję. Okazuje się przy tym, że wszystko, co takie cechy posiada oddziałuje niezależnie od pozostałych właściwości jako „coś miłego i infantylnego”. Dlatego też tkliwość w człowieku będzie budzić - jak przekonuje antropolog - w większym stopniu młody lew, aniżeli długonoga małpka.

Gehlen usiłuje wykorzystać etologiczne obserwacje w swojej koncepcji genezy sztuki. Punktem wyjścia czyni tezę, że pierwotny człowiek był konfrontowany $\mathrm{z}$ "nieprawdopodobnymi” zjawiskami natury, które postrzegał niezależnie od jakiejkolwiek biologicznej relewancji. Zjawiska te były podporządkowane abstrakcyjnej, tylko rudymentarnie odnoszonej do instynktu, czysto uczuciowej uwadze. Tego rodzaju „przekształcenie aktywnej, pełnej 
reakcji w przypływ uczuć"7 wyzwalało quasi-instynktowny wymóg uruchomienia zachowania, które byłoby adekwatne wobec zaistniałej sytuacji; ponieważ jednak z powodu redukcji instynktów człowiek nie dysponował z góry ustaloną formą reakcji, wymóg ten znajdował wyraz w kolektywnym działaniu, które pod względem formy przypominało instynktowną koordynację ruchową. „Nieokreślone zobowiązanie” wywołane apelatywnym sygnałem bodźca kluczowego było w pewnych sytuacjach realizowane na płaszczyźnie zbiorowego działania rytualnego i przybierało "pustą ceremonialną formę"8.

Szczególnie istotny jest dla Gehlena formalny charakter zachowania, ponieważ dzięki niemu rytuał otwiera się na dowolne, często sprzeczne ze sobą motywacje, które nie zniekształcają przebiegu ustalonych czynności. Zbiorowe ustanowienie formy rytualnej stanowi źródło normatywności powstającej instytucji, ustala podstawowe zakazy i powinności obowiązujące całą społeczność. W zachowaniu rytualnym brakuje bowiem jakiejkolwiek utylitarnej kalkulacji zysków i strat, jakiejkolwiek subiektywnej interesowności. Rytuał będący odpowiedzią na obiektywne, "nieokreślone zobowiązanie” opiera się na mimetycznym odzwierciedlaniu „doniosłego” dla całej wspólnoty zjawiska.

Dlatego musi on przedstawiać, ponieważ u jego podłoża nie leży żadne praktyczne działanie nastawione na przekształcanie rzeczy, tak że treścią działania staje się jego forma, określenie tego, jak być powinno: i właśnie to nazywamy naśladującym, przedstawiającym aktem? .

W działaniu rytualno-przedstawiającym dochodzi do wirtualizacji potrzeb, a obiekt uznany za sprzyjający przetrwaniu grupy (np. zwierzę łowne) bądź za potencjalne zagrożenie (np. pioruny) uzyskuje status samoistnego bytu, wobec którego wszyscy postępują w identyczny sposób, rezygnując z własnych potrzeb i interesów. Antropologicznie pierwotną reakcją na apelatywne bodźce jest dla Gehlena „akt nadawania imion” (Benennung) ${ }^{10}$. Nazywanie zjawisk stanowi bowiem podstawową formę odciążenia zarówno ludzkiej percepcji od nadmiaru wrażeń zmysłowych, jak i samego działania od zbędnych nakładów energii popędowej - „,...] albowiem język postrzegany jako mówienie jest równocześnie ruchem i doznaniem, a zatem zwrotnie

\footnotetext{
7 Tamże, s. 148.

8 Tamże, s. 43.

9 Tamże, s. 179.

10 Tamże, s. 142.
} 
odbieranym ruchem i o tyle właśnie działaniem" ${ }^{11}$. Nie tylko w perspektywie ontogenetycznej (omówionej w Der Mensch), ale również w filogenetycznej (jak pokazuje Urmensch) mowa oddramatyzowuje rzeczywistość, zdejmuje z niej stygmat kontyngencji i tajemnicy. Język wprowadza ponadto struktury porządku w nieustabilizowanej sferze popędowej, ukierunkowuje działanie i pozwala przekroczyć człowiekowi horyzont teraźniejszości. „Nazwa narzuca się jako pierwsza potrzebie orientacji i doniosłości" ${ }^{\prime 2}$. Pierwotne nazwy nie tylko abstrakcyjnie reprezentują stany rzeczy, ale przede wszystkim przejmują od nich na mocy sympatetycznego pokrewieństwa siłę sprawczą. Mowa służy zatem do symbolicznego oswojenia rzeczywistości, do przekształcenia jej w uniwersum sensownych związków. Dzięki językowi rozwija się komunikacja międzyludzka sprzyjająca koordynacji zbiorowych działań i tworzeniu więzi społecznych, a ponadto na płaszczyźnie podmiotowej uruchamia się proces apercepcji. Nieprawdopodobne, zadziwiające zjawiska wymuszają na człowieku nie tylko potrzebę adekwatnej reakcji motorycznej, ale również domagają się usensownienia. Dlatego „[...] nieznany, ale niejako od wewnątrz wymagany sens [...] stanowi istotną część składową numinotycznej sytuacji”13.

Najbardziej rozpowszechnionym w kulturach archaicznych przykładem nadawania sensu w sytuacji nieokreślonego zobowiązania są dla Gehlena praktyki wróżenia. Filozof odwołuje się tutaj do prac Lévy Bruhla, z którym łączy przekonanie, że struktury świadomości człowieka archaicznego i współczesnego różnią się od siebie w sposób zasadniczy ${ }^{14}$. Różnica dotyczy przede wszystkim sposobu pojmowania natury, która niegdyś była postrzegana przez człowieka jako uniwersum przesycone numinotycznymi zjawiskami.

Dla człowieka archaicznego nie istnieje jeszcze zneutralizowany, odczarowany świat zewnętrznych faktów, nie postrzega on natury jako czegoś prawdziwego bądź nie; ponieważ to, co nadnaturalne stanowi jeszcze nieodłączny wymiar samej natury, w dowolnym miejscu może ono wykroczyć z widzialnej rzeczywistości, daje o sobie znać w pewnych wyjątkowych stanach codzienności ${ }^{15}$.

\footnotetext{
11 Tamże.

12 Tamże.

13 Tamże, s. 139.

${ }^{14}$ Por. L. Lévy-Bruhl, Czynności umysłowe w społecznościach pierwotnych, tłum. B. Szwarcman-Czarnota, Warszawa 1992.

15 A. Gehlen, Urmensch, s. 104.
} 
Sytuacje, które współcześnie wydają się całkowicie indyferentne, dla człowieka archaicznego noszą w sobie oznaki czegoś niesamowitego, a zarazem znaczącego. Takie zjawiska jak błyskawica, trzęsienie ziemi, zaćmienie słońca czy księżyca, narodziny bliźniaków, ryzykowna wyprawa wojenna, dziwne zachowanie bydła, nagłe zachorowania etc. prowokują nieodparte „odczucie doniosłości” ${ }^{\prime 1}$. Świadkom takich wymownych zdarzeń narzuca się jednocześnie potrzeba zajęcia wobec nich stanowiska, podjęcia odpowiedniego działania. W rezultacie powstaje „[...] silne i złożone napięcie afektów, w które wnikają również hamujące siły lęku"17. Potrzeba reakcji staje się w tym przypadku wyrazem przymusu kompensacji zaburzenia równowagi afektów. Nazywanie oraz odczytywanie zjawisk na podstawie określonej konstelacji znaków służy w istocie przywróceniu homoestazy w emocjonalnym układzie człowieka. Jeśli zabiegi przynoszą pożądany skutek, stan napięcia stabilizuje się i uzyskuje „[...] trwałą formę zorientowanego odtąd «usposobienia»”"18. Na zewnątrz przejawia się ono w postaci rytualnego zachowania, u podłoża którego znajduje się wspólne kolektywne wyobrażenie. Jeśli proces ten zachodzi wyłącznie na poziomie jednostkowym, powstaje wówczas stan neurotycznego zaburzenia. Istotny okazuje się w tym przypadku społeczny charakter działania, który tworzy podstawę dla intersubiektywnie podzielanego przekonania, że określone bodźce wyzwalające kryją w sobie ukryte znaczenie ${ }^{19}$. Kultura staje się tym samym ogółem możliwych systemów symbolicznych, a człowiek - animal symbolicum.

Pojęcie symbolu używane w Urmensch składa się z dwóch powiązanych ze sobą określeń. Pierwsze odsyła do analizy symbolizacji ludzkiego postrzegania z Der Mensch, drugie zaś do schematu transcendencji, w którym filozof opisuje przekształcenie wartości użytkowej rzeczy w symboliczną wartość bytową, jakie zachodzi za pośrednictwem działania rytualno-przedstawieniowego. Tworzenie symbolicznych reprezentacji świata na poziomie percepcji (wzajemna transpozycja różnych modalności zmysłowych, np. postrzeganie wartości haptycznych) funkcjonuje jako conditio sine qua non działania przekraczającego instrumentalne odniesienie do świata. Symboliczna interpretacja określonych aspektów rzeczywistości obecna chociażby w stanie „ustabilizowanego napięcia” prowadzi do tego, że „nieokreślone zo-

\footnotetext{
16 Tamże, s. 140.

17 Tamże.

18 Tamże, s. 79.

${ }^{19}$ E. Cassirer, Esej o człowieku. Wstęp do filozofii kultury, tłum. A. Staniewska, Warszawa 1977, s. 80.
} 
bowiązane" zamienia się w „,...] określone, przypisane danemu wyzwalaczowi znaczenie, któremu raz na zawsze zostaje przyporządkowane specyficzne zachowanie"20.

Obok aktu nadawania imion oraz praktyki wróżenia działanie rytualno-przedstawieniowe stanowi podstawową formę reakcji na nieprawdopodobne i doniosłe dla życia zjawiska. Podczas gdy nazywanie artykułuje jedynie mgliste odczucie doniosłości, praktyki wróżebne zachodzą na wyższym poziomie interpretacji, zakładają bowiem rozumienie pewnych znaczących zależności. Natomiast w działaniu rytualno-przedstawiającym sens przekształcony $\mathrm{w}$ zbiorowe wyobrażenie realizuje się w praktyce posiadającej symboliczne znaczenie. Trzy wymienione reakcje odzwierciedlają zatem proces stopniowej komplikacji, wzrostu złożoności sensu.

Dotychczasowe analizy prowadzą Gehlena do przekonania, że sztukę archaiczną należy pojmować jako działanie kolektywne. Wyobrażenie izolowanego podmiotu-artysty i pasywnego odbiorcy z trudem daje się zastosować do współczesności, w odniesieniu do czasów prehistorycznych stanowi ono natomiast bezużyteczną fikcję. Protoformą sztuki jest zbiorowe działania rytualne, które z kolei filogenetycznie wywodzi się z rytualizacji występujących w świecie zwierzęcym ${ }^{21}$.

W filogenetycznym dziedzictwie dostrzegamy zachowanie, które z jednej strony, stanowi źródło sztuk przedstawiających, a z drugiej strony, musi wiązać się z określonymi najwcześniejszymi formami religii ${ }^{22}$.

Nawiązując do H. Kirchnera, antropolog interpretuje słynne naskalne malowidła neolityczne jako obrazowe obiektywizacje pierwotnych rytów przedstawiających ${ }^{23}$. Mimiczno-gestyczne przedstawienie zostaje tutaj przeniesione na płaszczyznę graficznej reprezentacji. Zdolność do tworzenia materialnych podobizn, obrazów ukazujących pewną doniosłą dla zbiorowości narrację symboliczną stanowi kolejny etap rozwoju instytucji religijnych

\footnotetext{
${ }^{20}$ A. Gehlen, Urmensch, s. 140.

${ }^{21}$ Liczne przykłady przytacza i omawia K. Lorenz. Chodzi między innymi o rytuały walk turniejowych, krzyku triumfalnego, tańce godowe etc. Więcej w: K. Lorenz, Tak zwane zło, tłum. A. Tuszyńska, Warszawa 1972.

${ }_{22}$ A. Gehlen, Urmensch, s. 124.

${ }^{23} \mathrm{H}$. Kirchner, Über das Verhalten des schriftlosen frühgeschichtlichen Menschen zu seiner Geschichte, Berlin 1954.
} 
będący oznaką wyższego stopnia rozwoju abstrakcyjnego myślenia, sztuki i techniki.

W paragrafie 31 Urmensch Gehlen wyróżnia dwa podstawowe typy przedstawiającego działania. Obok przedstawienia in materia, w którym wykorzystuje się jakąś formę reprezentacji (np. malowidła naścienne) wyróżnia przedstawienie in vivo, to znaczy naśladowcze uobecnienie czy ucieleśnienie istotnych i ryzykownych doświadczeń. Obydwa typy przedstawień stanowią stadia pośrednie procesu prowadzącego do powstania instytucji. Najstarszą formą przedstawienia stanowi cielesna mimesis - rytmizacja określonych przebiegów ruchowych, które artykułują imperatywny nakaz narzucony przez nieprawdopodobne i znaczące bodźce wyzwalające. Jako przykład Gehlen podaje tutaj taneczny rytuał pigmejów naśladujący zjawisko nowiu księżyca.

Rytualne tańce pigmejów mają charakter mimiczny [...] są rodzajem aktywnego rysunku (dessein en action), grawerunkiem czy też rzeźbą wzbogaconą o dodatkowy ruch. [...] Jeśli umieścimy w nawiasie późniejszą racjonalizację, to znaczy uznanie tego rytuału za formę «magii płodności», znajdziemy się blisko właściwych źródeł protomagii ${ }^{24}$.

Dzięki rytmizacji, standaryzacji i synchronizacji ruchów naśladowczych niepomiernie zwiększa się wyrazistość odtwarzanego zdarzenia - mimetyczne przedstawienie nadaje mu $\mathrm{w}$ rezultacie cechę "nad-wyrazistości” (Überprägnanz). Gehlen pisze w tym kontekście o samo-naśladowaniu przedstawiającego działania - „[...] za pośrednictwem rytmizacji i uzyskanej przez to nad-wyrazistości działanie naśladuje samo siebie, czy też przedstawia samo siebie, działanie zaś, które dzięki swojej nad-wyrazistości zajmuje stanowisko wobec siebie, staje się zdolne do tworzenia symboli”"25. Przedstawienie rytualne nie realizuje zatem żadnego pragmatycznego celu, ani nie stanowi bezpośredniej ekspresji afektów. Jego wartość symboliczna polega, z jednej strony, na autoteliczności osiągniętej za sprawą usamodzielnienia się zaakcentowanych postaci ruchowych, $\mathrm{z}$ drugiej natomiast strony, opiera się na imperatywnym potencjale, który urzeczywistnia się w wymiarze społecznym. Rytmizacja ruchu postrzegana jest przez członków danej grupy jako powinność, ponieważ sam akt naśladowania pełni już funkcję apelatywną. Okazuje się zatem, że nakaz płynący początkowo ze strony zewnętrznego zjawiska

\footnotetext{
${ }^{24}$ A. Gehlen, Urmensch, s. 145, 147.

${ }^{25}$ Tamże, s. 146.
} 
przeistacza się w rytuale w nakaz obowiązujący w sferze społecznej. „Inaczej mówiąc: przedstawiające naśladowanie wyrazistego wydarzenia przebiega $\mathrm{z}$ góry jako proces rozprzestrzeniający się $\mathrm{w}$ społeczeństwie: odczucie zobowiązania i potrzeba działania, które podzielają uczestnicy rytuału, przenosi się na jednorodne zachowanie, które wszyscy wykonują wzajemnie odnosząc się do siebie" 26 . W zachowaniu mimetycznym krzyżują się zatem dwa wymiary procesu naśladowania: $\mathrm{w}$ pierwszym wymiarze naśladowanie dotyczy numinotycznego zjawiska, $w$ drugim zaś dochodzi do wzajemnego naśladowania się uczestników rytuału. Samoistna wartość przedstawianego zdarzenia (obiektu) stapia się z samoistną wartością rytu jednoczącego grupę. Im silniejszy jest imperatywny charakter obiektu, tym silniejsza staje się moc powinności zawarta w przedstawiającym rytuale.

Wyrazistość postaci ruchowych wyrażonych przez mimikę, gesty, taniec i śpiew reprodukuje się w formie ich społecznego wykonania. Akty mimetyczne stopniowo usamodzielniają się i uzyskują status samowystarczalnych, sensownych działań. „Dzięki temu jednostka wchodzi w relację do bytu jako takiego, który, by wyrazić inaczej pojęcie statusu, sam siebie reprezentuje i nie ukazuje się już jako byt, który można zmienić." ${ }^{27}$ Naśladowcze przedstawienie zwierzęcia łownego utrwala tym samym jego „samoistną wartość bytową". Rytuał odrywa bodziec wyzwalający od przestrzenno-czasowego kontekstu, w którym ukazał się członkom wspólnoty, a przez to zawiesza jego wartość użytkową. Samoistna wartość bytowa obiektu zagęszcza się w akcie mimesis do postaci symbolu, którego normatywny charakter manifestuje się odtąd jako przymus uczestnictwa w rytuale.

Dzięki transpozycji korelatu naśladowczego przedstawienia na płaszczyznę obrazu, jego groza i numinotyczna moc uzyskuje konkretną postać, on sam zaś nabiera trwałości i uniezależnia się od kontyngentnych doświadczeń. Drapieżne zwierzę przestaje być odbierane jako bezpośrednie zagrożenie, lecz zaczyna uosabiać ryzykowność życia w ogóle

odczucie istnienia, które uświadamia, że nie ma nic poza tym światem, że mimo kryjących się $\mathrm{w}$ nim niebezpieczeństw zapewnia on osamotnionemu stworzeniu trwałe zaspokojenie potrzeb, uczucie to daje się wyrazić jedynie $\mathrm{w}$ symbolicznym, pełnym znaczenia przedstawieniu, w dramatycznej egzemplaryczności - w postaci ogromnego zwierzęcia ${ }^{28}$.

\footnotetext{
${ }^{26}$ Tamże, s. 147.

${ }^{27}$ Tamże, s. 80.

${ }^{28}$ Tamże, s. 55.
} 
Nie tylko zatem mimiczna, lecz również obrazowa forma przedstawienia służy stabilizacji zewnętrznego, jak i wewnętrznego świata. Taniec i sztuka kultowa mają bowiem moc wiązania i ujarzmiania nawet niezwykle silnych afektów

głód i lęk przed nim, pożądanie i chęć unicestwienia, odwaga i strach przed niebezpieczeństwem, wszystko to wnika w sensomotoryczny potencjał zintensyfikowanego i zrytmizowanego odczucia ruchu ${ }^{29}$.

W rytualnym przedstawieniu krystalizuje się i ujednolica stosunek człowieka do samego siebie i otaczającego go świata. Ściśle ustalony przebieg zachowań obrzędowych stanowi zarazem punkt odniesienia dla samoświadomości uczestników, której współtowarzyszy samoświadomość zbiorowa. Wraz z mimetycznymi rytuałami w zbiorowej świadomości zaczęły kształtować się również wyobrażenia bogów, półbogów, demonów - istot nadziemskich, choć partycypujących w codziennej rzeczywistości. Za Durkheimem, a przeciwstawiając się psychoanalizie, która wyobrażenia boskości wyprowadza $\mathrm{z}$ indywidualnej instancji superego, antropolog podkreśla ich społeczny charakter. Istoty boskie przeniesione na płaszczyznę przedstawienia uzyskują samoistną wartość bytową dzięki temu, że ich siła sprawcza przekracza wymiar obrazu ${ }^{30}$. Wyobrażenie stanowi $\mathrm{w}$ tym przypadku korelat quasi-instynktownej reakcji, która w mimicznym przedstawieniu uzyskuje swoją pierwotną symboliczną postać. Wyobrażenie autonomizuje się zatem, kiedy postać bóstwa zostaje utrwalona $\mathrm{w}$ rytmicznie skoordynowanych sekwencjach ruchów. Odpowiednio wyakcentowana „nad-wyrazistość” figur ruchowych niejako cieleśnie uzmysławia transcendentny wymiar przedstawianego bóstwa, jego niezwykłość i samoistnośćc ${ }^{31}$.

Bóstwo staje się swoistym ośrodkiem krystalizacji zarówno jednostkowej, jak i zbiorowej samoświadomości. Rytuał, w jakim ono się pojawia, definiuje rzeczywistość człowieka archaicznego, nasyca ją ukrytymi znaczeniami, a przez to czyni swojską i zrozumiałą. Transcendentny, ale objawiający się w postaci systemu widzialnych znaków wymiar sacrum staje się normą, „[...] gdy zwierzęta, źródła, rozmaite miejsca, góry, drzewa mogą zostać rozpozna-

\footnotetext{
${ }^{29}$ Tamże, s. 152.

${ }^{30}$ Tamże, s. 154.

${ }^{31}$ Gehlen zwraca uwagę, że w kulturach archaicznych teogoniczną moc mają również marzenia senne, w których bóstwa manifestują się wybranym jednostkom. Kluczową rolę odgrywa ponadto ludzka skłonność do antropomorfizacji naturalnych zjawisk.
} 
ne jako siedziby wyższych istot, gdy wyprowadza się z nich wiążące reguły, gdy zatem działanie orientuje się według miary znaczącej rzeczywistości tych rzeczy i przejmuje od nich zobowiązanie, które zaczyna nad nim ciążyć"32. Przedstawienie rytualne stapia ze sobą podmiot i przedmiot działania uczestnik rytuału nie reprezentuje, nie wchodzi w rolę, lecz bezpośrednio ucieleśnia przedstawianą istotę. Pomiędzy porządkiem tego, co przedstawiane i przedstawiające powstaje nierozdzielne kontinuum. Poprzez to, że imperatywna moc bodźca wyzwalającego manifestuje się bezpośrednio w samym przedstawieniu, moment popędowy opatrzony znakiem powinności przenosi się na rytualne działanie. W ten sposób sam rytuał uzyskuje apelatywny charakter, który zapewnia mu stabilność i dalsze trwanie. „Powinność zawarta w rytuale umożliwia jego powtarzanie, ku któremu ciążą ciągłość oraz inwariancja stabilizujących momentów, które rytuał umieszcza w świadomości, zachowaniu i zewnętrznym świecie" ${ }^{33}$.

Przedmiotem rytualnego przedstawienia są nie tylko kontyngentne, nieprawdopodobne zjawiska, lecz również stany rzeczy związane bezpośrednio z przetrwaniem człowieka takie jak: pożywienie, rozmnażanie, narodziny, życie, umieranie, śmierć. Jak stwierdza antropolog, w każdorazowym przypadku chodzi o „[...] przedstawienie owych punktów zapalnych rzeczywistości; wznosząc się ponad doraźną potrzebę, [uczestnicy rytuału] jednocześnie ją utrwalają" ${ }^{34}$. Moralne osiągnięcie rytualno-przedstawiającego działania polega na tym, że zagrażające ludzkiemu istnieniu siły rzeczywistości (a patrząc na to z perspektywy subiektywnej - destrukcyjne impulsy popędowe) zostają w nim całkowicie przezwyciężone. Rytuał inscenizuje walkę o byt, a zarazem symbolicznie unaocznia pełne zwycięstwo człowieka oraz uzyskaną w tej walce zdobycz, jaką jest gwarancja przetrwania.

Niezwykła produktywność zachowań rytualnych wynika paradoksalnie z ich formalizmu. To, co wśród wielu antropologów poszukujących ukrytej semantyki w obrzędowych czynnościach budziło rozczarowanie, to znaczy ubóstwo treści, dla Gehlena świadczy o ich kulturotwórczej mocy. Autoreferencyjność „znaczenia” rytuału, jego niejęzykowy charakter podkreślany przez repetytywną, obligatoryjną i ściśle uregulowaną strukturę umożliwia bowiem „inscenizację bezczasowości” oraz stwarza szansę na rozwinięcie

\footnotetext{
32 A. Gehlen, Urmensch, s. 119.

${ }^{33}$ Tamże, s. 157.

${ }^{34}$ Tamże, s. 56.
} 
ekscentrycznego samoodniesienia i uprzedmiotowienia, a zarazem utrwalenia złożonych kompleksów ludzkich potrzeb.

Sztuka archaiczna wywodzi się z quasi-instynktownych zachowań stanowiących reakcję na nieprawdopodobne zjawiska. Najwcześniejsze rytualne i wizualne przedstawienia wynikają $z$ bezinteresownej postawy wobec świata i dopiero wtórnie uzyskują funkcję społeczną. Szczególny rodzaj rzadkich i niezwykłych fenomenów natury (spektralne barwy, harmonia, symetria układu poszczególnych elementów, regularność ruchu etc.) wyzwala w człowieku odczucie podziwu nie mające nic wspólnego z odczuciem tego, co przyjemne bądź pożyteczne, lecz stanowiące odrębną modalność aksjologiczną, która wyraża się w doznaniu intensyfikacji życia. Tutaj właśnie, jak przekonuje antropolog, kryją się filogenetyczne źródła przeżycia piękna, które pozwala archaicznemu człowiekowi przekroczyć wąski krąg codzienności. Niestety Gehlen nie rozwija dalej swoich analiz w kierunku opisu przejścia od przedstawienia rytualno-ideatywnego do form stricte estetycznych. Urmensch und Spätkultur stanowi bowiem przede wszystkim rozprawę traktującą o początkach społecznych instytucji oraz ich losie we współczesnej kulturze. Problem sztuki dyskutowany jest wprost w późniejszej pracy Zeit-Bilder.

Zeit-Bilder jest jedyną obszerną rozprawą Gehlena z zakresu estetyki. Jako antropolog i socjolog w jednej osobie próbuje on wypracować wielostronną refleksję, która czerpiąc z różnych źródeł, metod, szczegółowych analiz, będzie w stanie dotrzeć do ogólnych filozoficznych ustaleń. W punkcie wyjścia swoich rozważań Gehlen zakreśla uproszczoną historiozoficzną perspektywę rozwoju sztuki. Jej najstarszą, idealistyczną postacią jest sztuka feudalnego średniowiecza, kolejną odrębną formację stanowi sztuka przedindustrialnego mieszczaństwa, obecnie zaś dominuje abstrakcyjna sztuka stechnicyzowanej kultury. Trzy wymienione okresy rozwoju sztuki przypisane są do odmiennych systemów odniesienia. Wczesna sztuka, do której Gehlen zalicza dzieła religijne i mitologiczne, ale również malarstwo historyczne i symboliczne, była odniesiona do idealnej sfery prawd absolutnych, natomiast realistyczna sztuka mieszczańska ze swoją naczelną zasadą mimesis skupiała się na estetycznym oswajaniu natury, podczas gdy współcześni artyści autorefleksyjnie zwrócili się ku samemu medium sztuki, czyniąc głównym przedmiotem twórczości własną podmiotowość. Antropolog opisuje tę społeczno-historyczną przemianę jako rezultat wzrastających aspiracji mieszczaństwa, uwol- 
nienia artystów od klerykalnych i politycznych zleceniodawców, a przede wszystkim - jako skutek autonomizacji sztuki.

Bardziej szczegółowo i przekonująco filozof opisuje prezentuje ten proces jako rozwój zachodzący w obrębie samego przedstawienia, pisząc w tym kontekście o przemianie „wewnętrznej racjonalności obrazu”, która stanowi obiektywny korelat „percepcyjnego nastawienia odbiorcy” ${ }^{35}$, względnie „wymogu, jaki przedstawienie stawia odbiorcy"36. Odmienne paradygmaty recepcji opisuje filozof $w$ tradycyjnej terminologii jako relację między naocznością a pojęciem, jaka zachodzi w akcie odbioru dzieła sztuki. Tam, gdzie Kant nie rozróżnia odmian recepcji historycznie zmiennych form obrazu i określa piękno in genere jako to, co wywołuje bezinteresowne upodobanie bez pośrednictwa pojęcia i doświadczenie estetyczne definiuje jako swobodną harmonijną grę władz poznawczych, Gehlen stara się wykazać przesunięcia we wzajemnej relacji obydwu instancji (wyobraźni i intelektu).

Antropolog rozróżnia przy tym, na podstawie teorii Panofsky'ego, powierzchnię obrazu (barwy, linie, płaszczyzny, faktura) oraz treść obrazu. Jedność treści i powierzchni obrazu odzwierciedla motywy pierwotne, w obrębie których sytuują się motywy wtórne - dodatkowe symboliczne znaczenie. Na tym tle Gehlen opisuje rozwój malarstwa, to znaczy rozwój jego kolejnych historycznych postaci jako sukcesywną redukcję wymienionych warstw obrazu. Idealistyczne dzieła sztuki wykazują zarówno pierwotne, jak i wtórne motywy. Rozpoznanie pierwotnych motywów tożsame z identyfikacją przedstawionego obiektu zachodzi na poziomie przedpredykatywnej refleksji, która dociera do „czysto optycznej, intuitywnie dostępnej” płaszczyzny obrazu. Natomiast uchwycenie wtórnych motywów zakłada odniesienie do szerszego symbolicznego kontekstu przedstawienia, zakłada tym samym ujęzykowioną, pojęciową wiedzę wstępną - pewien rodzaj skanonizowanej narracji, jakiej dostarcza odbiorcy kultura. Rozpoznanie odsłania pierwotny motyw obrazu, natomiast deszyfrująca interpretacja nasyca uchwycone uprzednio motywy dodatkowymi sensami. W przedpredykatywnej refleksji odbiorcy krzyżuje się zatem niezmysłowość pojęcia z irracjonalnością oglądu. Owa irracjonalność „wewnątrzoptycznej inteligencji” nie oznacza bynajmniej potoku nieuporządkowanych wrażeń zmysłowych, ponieważ według Gehlena, percepcja zostaje ustrukturyzowana jeszcze przed fazą pojęciowej kategoryzacji. Innymi słowy czysty, niepojęciowy ogląd posiada już pewne

\footnotetext{
35 Tamże, s. 27.

${ }^{36}$ Tamże, s. 39.
} 
kognitywne cechy, które trafnie opisuje psychologia postaci. Kluczową kategorią w opisie procesu recepcji dzieła sztuki jest pojęcie rozpoznania, które oznacza przedjęzykowy proces łączący sferę naoczności i pojęcia. „Relacja pomiędzy obydwiema instancjami z reguły nie jest krytyczna, ponieważ bezpośrednie dane wrażeniowe $\mathrm{w}$ każdym akcie percepcji ukazują się jako akty już zinterpretowane, dlatego rozpoznanie nie wymaga zazwyczaj w pełni wyartykułowanego pojęcia." ${ }^{37} \mathrm{~W}$ najstarszej postaci sztuki obraz nie przedstawia tylko dającego się rozpoznać obiektu, lecz jednocześnie zawsze reprezentuje pewną ogólną ideę

Wszystkie te obrazy zakładają określone pola znaczeniowe, a mianowicie te same, które tkwią w artyście, odbiorcy i obrazie. Nawet jeśli średniowieczne malarstwo ołtarzowe było skierowane do niepiśmiennych, to jednak zawsze zakładało u nich pewną podstawową znajomość ze słuchu świętych historiii ${ }^{38}$.

Sztuka realistyczna przynosi radykalną zmianę w sposobie kształtowania przedstawienia, odchodzi bowiem od wtórnych motywów, redukując do minimum warstwę symbolicznych konotacji. Proces ten radykalizuje się we współczesnej sztuce, która rezygnuje całkowicie z figuratywnych przedstawień i ogranicza się do form i barw. Istotne tutaj jest przy tym to, że proces redukcji treści zbiega się z redukcją pojęciową. Symboliczne treści wymagają zasobów wyuczonej, dyskursywnej wiedzy, podczas gdy prosta identyfikacja obiektów obywa się już bez świadomej pojęciowej artykulacji, ponieważ rozpoznanie zarówno w potocznej percepcji, jak i w postrzeganiu obrazu, jest z góry zapośredniczone przez pojęcia:

albowiem każdy realny przedmiot jest w ludzkiej świadomości przeniknięty pojęciami, pojęcie i ogląd stapiają się w niej, a utrzymuje je w tym połączeniu akt rozpoznania - ten sam mechanizm, który również łączy obraz z jego motywem ${ }^{39}$.

Dlatego figuratywne obrazy, niezależnie od tego, czy zawierają w sobie symboliczne konotacje, czy nie, dają się zasadniczo wyrazić w postaci propozycjonalnej wiedzy i w tym właśnie sensie można je określić jako „mówiące

\footnotetext{
37 Tamże, s. 8.

38 Tamże, s. 10.

39 Tamże, s. 53.
} 
dzieła sztuki” ${ }^{40}$, „nieme” pozostają natomiast obrazy abstrakcyjne ${ }^{41}$, ponieważ po wykluczeniu przedmiotowych motywów pozostają w nich tylko układy barw i form. Gehlen zadaje w tym kontekście pytanie, do jakich warstw psychicznych odwołują się obrazy nie zawierające żadnej pojęciowej treści?

W odpowiedzi filozof wskazuje, że tego rodzaju sztuka opiera się przede wszystkim na racjonalności sui generis: na ,intelektualnym charakterze percepcji”. Nie należy go jednak mylić z racjonalnością w sensie dyskursywnej wiedzy, chodzi tu bowiem o tak zwaną racjonalność obrazu definiowaną jako „nie dająca się sformułować wydajność” wynikająca $z$ niepojęciowego "przepracowania widzialności” ${ }^{42}$. Ta dość enigmatyczna definicja nawiązuje do estetycznej teorii Fiedlera, który opierał swoje analizy dzieł sztuki na elementarnym rozróżnieniu czynnika pojęciowego i obrazowego. Nawiązując do niego, Gehlen stwierdza:

Energia oglądu i myślenia znajdują się względem siebie w relacji wykluczenia i jeśli w praktycznym życiu pojęcie pokrywa się z naocznością, to na płaszczyźnie obrazu zachodzi przeciwstawna relacja. Wewnętrzna racjonalność obrazu osiągnięta w ciągłej refleksji skierowanej na to, co widzialne oraz w jego ustawicznym przetworzeniu, całkowicie wystarcza sama sobie - jak wiadomo, można w pełni przyswoić sobie obraz, nie odczuwając potrzeby artykułowania tego w pojęciach ${ }^{43}$.

Charakterystyczne dla współczesnej sztuki przełamywanie nawyków percepcyjnych za pośrednictwem świadomej interferencji płaszczyzny i przedmiotu obrazu, intensyfikacji walorów kolorystycznych, deformacji obiektu aż do jego całkowitego rozpuszczenia, narusza „[...] oczywistości nawykowego aktu rozpoznania"44. Sztuka eksperymentująca z widzialnością przedmiotu pobudza mechanizmy percepcyjne, które nie operują w wymiarze „optyczno-pojęciowym":

Ponieważ abstrakcyjny obraz równocześnie z przedmiotem usuwa rozpoznanie, jawi się jako irracjonalny, stąd powstaje pytanie dokąd przesunęła się pojęciowość przenikająca nasz ogląd [...]. Dalej należałoby zapytać, jakie warstwy

\footnotetext{
40 Tamże, s. 187.

${ }^{41}$ Tamże, s. 66.

42 Tamże, s. 61.

${ }^{43}$ Tamże.

${ }^{44}$ Tamże, s. 53.
} 
duszy porusza obraz - z pewnością takie, które znajdują się poniżej poziomu rozpoznawania, a zatem poziomu percepcji opisywanego przez psychologię postaci [...], obszary bezpośredniej wewnątrz-optycznej refleksji oraz obszary zbliżone do centrów słowotwórstwa [...] Istnieje bowiem, o czym od dawna wie psychologia, bezpośrednia i nierozwinięta racjonalność oka samego, na której eksperymentuje sztuka ${ }^{45}$.

Współczesna sztuka począwszy od późnego Moneta jest dla Gehlena tak fascynująca, ponieważ ujawnia skądinąd „trudną do uchwycenia, wewnętrzną inteligencję" percepcji, a zatem uwidacznia procesy postrzeżeniowe, które nie mieszczą się w codziennym, nawykowym sposobie postrzegania świata. Ludzka percepcja, podobnie jak język, ma na wskroś symboliczny charakter i przybiera formę procesu kołowego.

Skomplikowane procesy koordynacji ruchu ciała, oka i dotyku ręki odbywające się w obrębie funkcjonalnych kręgów działania, stopniowo strukturyzują obraz rzeczywistości, coraz bardziej oddalając człowieka od bezpośredniego nacisku bodźców. W duchu pragmatyzmu Gehlen stwierdza, że „dojrzały”, uformowany już obraz świata jest w wysokim stopniu zapośredniczony przez naszą własną aktywność. W istocie postrzegamy rzeczywistość, której szczegóły są dane tylko symbolicznie poprzez zarys postaci, skalę barw, różnice wielkości, odcienie, skróty, w ten sposób jednak, że „wartości użytkowe i towarzyszące”, jak np. suchość, struktura materiału, ciężar, odległość, czy „poręczność” rzeczy, są nam dane jednocześnie optycznie. Dostrzegamy zatem gładkość klamki, miękkość owocu, twardość stali, chociaż wrażenia te nie mają pierwotnie charakteru wizualnego. „Nasz zmysłowy świat jest zatem symboliczny, co znaczy: sugestie ruchowe, skróty, przednie strony obiektów, cienie, połyski, rzucające się w oczy cechy barw oraz postaci wystarczająco anonsują masę przedmiotu. Biologiczna celowość tego faktu polega, jak już powiedzieliśmy, na odciążeniu i przyspieszeniu reakcji, które dzięki temu stają w ogóle możliwe, ale przede wszystkim na tym, że całościowy ogląd może zaistnieć jedynie na polu symbolicznym. Istotne jest tutaj to, że „nie ma już potrzeby zagłębiania się w bogactwo zmysłowych treści, ponieważ odciążenie umożliwia przegląd całego pola symbolicznych sugestii”" ${ }^{2}$. W przeciwieństwie do zwierząt człowiek musi poddać się autodyscyplinie, samodzielnie kształtować swoją zmysłowość, na własną rękę zdobywać doświadczenia, a co najważniejsze, czyni to zazwyczaj niezależnie od swoich fizycznych potrzeb.

45 Tamże, s. 16.

${ }^{46}$ A. Gehlen, Der Mensch. Seine Stellung in der Welt, GA 3.2, s. 199. 
Differentia specifica naszej percepcji tkwi właśnie w bezinteresownej komunikacji ze światem rzeczy, której zawdzięczamy zdolność do postrzegania „obiektywnych” własności świata. Postrzegane obiekty nie są zatem jedynie korelatami naszych doraźnych potrzeb, gdyż zawsze zawierają w sobie pewną nadwyżkę treści, pewien rezerwuar możliwych zastosowań wykraczających poza aktualną motywację. Nie oznacza to bynajmniej, że nasze postrzeganie świata całkowicie uwalnia się od wcześniejszych stadiów formowania zmysłowości. Nawet „odciążona”, usymboliczniona percepcja zawiera bowiem elementy motoryczne w postaci „aperceptywnych ruchów” (dotykanie, nasłuchiwanie, patrzenie, smakowanie, etc.) i współodczuwanych przebiegów postaciowych.

Współczesna sztuka próbuje odsłonić wskazane powyżej, nieuświadamiane bądź marginalizowane na co dzień obszary widzialności świata. Artysta, narzucając sobie surowe rygory autodyscypliny, poddaje przetworzeniu pierwotne momenty widzenia i wydobywa na jaw to, co paradoksalnie bliskie, choć nieznane. Gehlen analizuje w swojej pracy bardzo wiele przykładów z zakresu malarstwa, szczególną uwagę poświęca przy tym twórczości P. Klee, która stanowi dla niego paradygmat peinture conceptuelle - sztuki konceptualnej, czyli sztuki opartej na teoretycznym fundamencie ${ }^{47}$. Obrazy szwajcarskiego malarza odsłaniają mianowicie rozmaite prawidła widzenia, takie jak strukturyzowanie tła i pierwszego planu, operowanie jakościowymi całościa$\mathrm{mi}$, transponowanie postaci, które funkcjonują poniżej progu rozpoznawania i pojęciowej racjonalności. Gehlen określa je mianem „racjonalności oka” bądź za H. Readem - „niedyskursywnym, imaginatywnym rozumem”48.

Już we wcześniejszym artykule Formen uns Schicksale der Ratio (1943) filozof siedem typów „nieokreślonego pojęcia obejmującego takie terminy jak ratio, racjonalność, racjonalny, etc." ${ }^{39}$ : zdolność ujmowania stanów rzeczy ze względu na określone przedmiotowe aspekty, celowo-racjonalne działanie, racjonalizacja prelogicznie odczutych „znaczących aspektów” rzeczywistości, systematyzacja, transpozycja określonych form zachowania na formę zarządzania bądź organizacji, sublimacja i wreszcie zdolność do zwiększania złożoności stanu rzeczy. Pierwsze cztery typy racjonalności występują, zdaniem

\footnotetext{
${ }^{47}$ Nie należy mylić tego określenia z nazwą nurtu malarskiego powstałego w latach 60 . $\mathrm{XX}$ wieku. Terminu peinture conceptuelle użył po raz pierwszy Guillaume Apollinaire w stosunku do kubizmu, chcąc podkreślić intelektualny charakter tego malarstwa - Gehlen używa go właśnie w tym znaczeniu.

${ }^{48}$ A. Gehlen, Zeit-Bilder, s. 62.

${ }^{49}$ A. Gehlen, GA 4, s. 306.
} 
filozofa, już na poziomie percepcji, która strukturyzuje wrażenia optyczne, ustala kauzalne powiązania i wyznacza systemy odniesienia. Przy czym paradoksalnie postulowana przez niego racjonalność oka obejmuje „irracjonalne" formy i barwy. Wydaje się, że w tym punkcie Gehlen padł ofiarą własnej niezbyt trafnie wybranej terminologii. Konsekwentnie odczytując jego rozważania na temat racjonalności i irracjonalności postrzegania, musielibyśmy przyjąć bowiem dwustopniowy model percepcji oparty na dualizmie dyskursywnego „rozpoznania” przedmiotów i symboli sztuki realistycznej oraz niepojęciowego, a zatem irracjonalnego „rozpoznania”, które odnosi się do malarstwa abstrakcyjnego. Taka opozycja nie jest jednak bynajmniej zamierzeniem Gehlena, ponieważ ani sztuka symboliczna nie ogranicza się do aktu pojęciowego rozpoznania i jego werbalizacji, ani też sztuka abstrakcyjna nie wyklucza bez reszty dyskursywnego ujęcia. Antropolog usiłuje raczej wypracować bardziej dynamiczny model percepcji na podstawie wewnętrznie zróżnicowanego pojęciea refleksji. W Zeit-Bilder możemy wyróżnić pięć form refleksji: subiektywny akt świadomości, „chroniczny” akt świadomości w znaczeniu trwałego stanu życia psychicznego, teoretyczną refleksję artysty w omówionym powyżej sensie, następnie optyczną oraz pojęciową refleksję odbiorcy.

W ogólnym ujęciu refleksja oznacza dla Gehlena akt, w którym dochodzi do nakładania się dwóch rodzajów przeżyć, w wyniku czego świadomość zostaje na powrót odniesiona do samej siebie $e^{50}$. Antropolog stwierdza, że refleksja stała się współcześnie stanem chronicznym, dlatego główne zadanie artysty polega na tym, żeby podwyższyć stopień optycznego napięcia odbiorcy, a tym samym - pobudzić jego optyczną refleksję. Zadanie to zostaje najpełniej zrealizowane wówczas, gdy obraz ukazuje wielowarstwowość przedstawienia, jego powierzchnia staje się suwerennym planem, a przy tym nie dochodzi do całkowitego porzucenia figuralności. Tego rodzaju metoda malarska zaczęła się rozwijać począwszy od prac Cézanne’a i van Gogha, osiągając apogeum w twórczości kubistów. Kubizm jest dla Gehlena szczególnie ważny, ponieważ precyzyjnie odsłania stereometryczną strukturę przedmiotów, rozbijając je na szereg osobnych, występujących obok siebie płaszczyzn. Dzięki temu zabiegowi spojrzenie widza zostaje wprowadzone do wnętrza obiektu i pochwycone przez usamodzielnioną płaszczyznę obrazu. Kubizm, a $\mathrm{w}$ zasadzie całe malarstwo abstrakcyjne $\mathrm{w}$ rozumieniu gehlenowskim, otwiera przed filozofią problem bezpojęciowości swoich konstrukcji, która

${ }^{50}$ A. Gehlen, Zeit-Bilder, s. 62. 
zbiega się z zahamowaniem dyskursywnego aktu rozpoznania. Innymi słowy peinture conceptuelle na nowo definiuje tradycyjne napięcie między pojęciem a oglądem - staje się ono bowiem sztuką na wskroś refleksyjną w tym sensie, że przenika je zarówno teoretyczna refleksja twórcy, jak i optyczna refleksja odbiorcy, który zostaje pobudzony do werbalizacji swojego przeżycia.

Doświadczenie estetyczne w obliczu współczesnych dzieł sztuki określa Gehlen za pomocą neologizmu „optycyzm siatkówki”. Wyrażenie to oddaje iteratywną grę stymulacji i destrukcji, w której obraz „równocześnie pobudza i odrzuca pojęciowe myślenie" ${ }^{1}$. Choć filozof nie powołuje się na Kanta, wyraźnie możemy dostrzec w tym miejscu analogię do czwartego momentu sądu o pięknie z Krytyki władzy sądzenia, gdzie czytamy: „Piękne jest to, co bez pomocy pojęcia poznaje się jako przedmiot koniecznego upodobania" ${ }^{52}$. Również odbiorca abstrakcyjnego dzieła sztuki rozpoznaje w nim pewną ogólną, narzucającą się regułę, pod którą nie potrafi jednak podpiąć żadnego trafnego pojęcia, a przy tym zakłada powszechną ważność swojego rozpoznania. W świetle koncepcji Gehlena odpada rzecz jasna kantowska kategoria piękna, ale ważność zachowuje wskazany czwarty moment sądu smaku byłby to zatem paradoksalny "moment modalności upodobania w pięknie bez piękna”.

Antropolog opisuje proces tworzenia i recepcji dzieła sztuki jako funkcjonalny krąg działania oparty na sprzężeniu zwrotnym. Działanie zarówno wytwórcze, jak i odtwórcze nie przebiega liniowo od z góry ustanowionego celu do jego realizacji, lecz zawsze biegnie przez pośrednie ogniwa psychiczne, postrzeżenia, reakcje motoryczne, ruchy własne ku przedmiotom świata zewnętrznego i z powrotem. Kiedy na płaszczyźnie rzeczy zdarza się seria sukcesów i niepowodzeń, które za pośrednictwem organów sensorycznych są zwrotnie meldowane do centrum nerwowego, podmiot działania może zmodyfikować sposób podejścia, zmieniać próbne ruchy, aż ostatecznie na płaszczyźnie rzeczowej osiągnie sukces czy to w postaci wykonania dzieła, czy też w formie wglądu w jego sens.

Wytworzenie obrazu dokonuje się niejako z dwóch stron: jako działanie oraz jako jego każdorazowy skutek na powierzchni malowidła. Kiedy artysta czerpie inspirację z «śladu» własnej czynności, uruchamia się proces kołowy, który

\footnotetext{
${ }^{51}$ A. Gehlen, Zeit-Bilder, s. 150.

${ }^{52}$ I. Kant, Krytyka władzy sądzenia, Warszawa 1986, s. 124.
} 
obejmuje powstające dzieło, rękę i oko, a każde z tych ogniw jest zmienną podlegającą ciągłym modyfikacjom ${ }^{53}$.

Podobnie jako proces kołowy Gehlen opisuje autorefleksyjność współczesnej sztuki, która tworząc, zarazem «kontempluje» warunki swojej możliwości ${ }^{4}$.

Doświadczenie estetyczne oprócz poznawczej funkcji odgrywa również ważną rolę jako instancja odciążająca człowieka od nadmiernych obciążeń, jakie stawia przed nim życie społeczne. Jednostka poddawana jest bowiem zalewowi bodźców, strzępów informacji, nadmiaru regulacji prawnych, które stały się nieuchronnym produktem ubocznym stechnicyzowanej kultury. Dawniejszy system instytucji, dający aksjologiczne i praktyczne oparcie dla rozwoju indywiduum, został zastąpiony obecnie anonimową superstrukturą - systemem sprzęgającym w sobie nowoczesną technologię, naukę i gospodarkę. Dlatego też, jak podkreśla antropolog w odczarowanym świecie wzrosło niezmiernie zapotrzebowanie na „oazę subiektywnej wolności” ${ }^{5}$, jakiej dostarczyć może sztuka, o ile zrezygnuje z egzystencjalnego patosu i narzucania odbiorcom światopoglądowych, politycznych czy religijnych idei. Przede wszystkim zaś sztuka powinna odciążać człowieka od nadmiernych obciążeń moralnych, jakie nakłada nań społeczeństwo. Fakt, że zyskała obecnie instytucjonalną autonomię, a jednocześnie uwolniła się od konkretnych społecznych funkcji, czyni ją doskonałym instrumentem kompensowania społecznych i psychologicznych niedostatków jednostki.

Podsumowując rekonstrukcję estetycznych wątków w filozoficznej antropologii A. Gehlena, możemy wyróżnić dwie fazy ewolucji jego poglądów. W pierwszej, związanej z pracą nad teorią instytucji, filozof prezentuje koncepcje genezy twórczości artystycznej z zachowań rytualno-przedstawiających, przy czym podkreśla zasadniczą odmienność sztuki archaicznej i współczesnej. Pierwsze dzieła sztuki były wyrazem symbolizacji pierwotnych zachowań naśladowczych. Sztuka stanowiła integralną część społecznej praxis. Nieprawdopodobne ornamentalne zjawiska przyrodnicze wyzwalały quasi-instynktowne reakcje, które tworzyły podłoże dla zrytualizowanych ruchów będących swoistą odpowiedzią na niecodzienny impuls płynący z zewnętrznego otoczenia. W drugiej fazie twórczości filozof poświęca całą monografię zagadnieniom estetycznym. W centrum uwagi znajduje się współ-

\footnotetext{
${ }^{53}$ A. Gehlen, Zeit-Bilder, s. 192.

${ }^{54}$ Tamże, s. 158.

${ }^{55}$ Tamże, s. 196.
} 
czesna sztuka abstrakcyjna odczytana jako swoiste laboratorium, w którym artyści eksplorują głębokie, niezbadane warstwy ludzkiej percepcji. W świetle ogólnych założeń antropologicznych współczesna sztuka odgrywa ważną rolę jako instancja odciążająca człowieka od wymogów narzucanych przez coraz bardziej nieprzejrzystą i skomplikowaną rzeczywistość społeczną. Antropologiczna estetyka powinna dostarczyć odpowiednich narzędzi pojęciowych, które ułatwiłyby odbiorcom uchwycenie i zwerbalizowanie nowych przeżyć estetycznych.

\begin{abstract}
The Aesthetic Motives in the Philosophical Anthropology of Arnold Gehlen

Keywords: anthropology, aesthetics, symbol, instinctive reaction, ritual-presenting actions, releasing stimulus, beauty, rationality

The author of the article reconstructs the aesthetic motives in Arnold Gehlen's project of philosophical anthropology. The first part of the essay presents the process of emerging of artistic creativity from ritual-presenting actions. In the second part author elaborates the conception of abstract art, which Gehlen treats as a specific laboratory in which artists explore the possibilities of deep, previously undiscovered layers of human perception.
\end{abstract}

